\title{
Homeobox Protein Hox-B1
}

National Cancer Institute

\section{Source}

National Cancer Institute. Homeobox Protein Hox-B1. NCI Thesaurus. Code C162632.

Homeobox protein Hox-B1 (301 aa, $32 \mathrm{kDa}$ ) is encoded by the human HOXB1 gene.

This protein is involved in anterior-posterior patterning and facial nerve development. 